\title{
Teachers and Learners Level of Computer Literacy to Enhance E-education in Classroom: A Case Study of Six Public Secondary Schools in Atteridgeville Township in South Africa
}

\author{
Olika Moila \\ Moses Makgato
}

Department of Educational Studies, Tshwane University of Technology

Doi:10.5901/mjss.2014.v5n23p1017

Abstract

The use of ICT in teaching and learning in classroom is determined by the level of computer literacy by both teachers and learners. This paper presents the level of computer literacy in teachers and learners for the use of educational technologies in classroom at the six schools at Gauteng's Tshwane South District 4 (TSD 4). The study used both quantitative and qualitative approach in its methodology, by using questionnaires and interviews to collect data from both teachers and learners. The participants of the study were 24 teachers and 670 learners from the six schools. Data from questionnaires were analysed by means of frequencies, tables, means and standard deviations. The qualitative data from the interviews with 6 teachers and 6 School Management Team members were analyzed by reading repeatedly the transcripts in order to identify the patterns, categories and themes using relevant codes. These themes were presented and discussed in a narrative way together with some verbatim.

Keywords: ICTs; integrate; teaching and learning; challenges; implement

\section{Introduction}

The White Paper on e-Education, DoE, (2004) states that Information and Communication Technologies (ICTs) are the combination of networks, hardware and software as well as the means of communication, collaboration and engagement that enable the processing, management and exchange of data, information and knowledge.

The rapid development in ICTs have made tremendous changes in the twenty-first century, as well as affected the demands of modern societies. Recognizing the impact of new technologies on the workplace and everyday life, today's educational institutions try to restructure their educational programs and classroom facilities, in order to minimize the teaching and learning technology gap between developed and the developing countries. This restructuring process involves effective integration of ICTs into the curricula in order to provide learners with knowledge of specific subject areas in an attempt to enhance meaningful learning. However, this is not the case at the six public secondary schools in Atteridgeville at the TSD 4. The challenges that hinder effective ICT integration to enhance teaching and learning at the schools prompted this study. To this end, Roblyer, (2004), argues that one of the things that make teaching so challenging is that it goes on in an environment that mirrors and sometimes magnifies some of societies' most profound and problematic issues and adding ICTs to this mix makes the situation even more complex, yet to integrate them successfully into their teaching, educators need to adapt to the effects that ICTs have on education.

It has also been noted that schools have been slow to adopt ICT as an integral tool across the curricula. Teachers and learners lack the necessary knowledge and skills to use educational technologies effectively for teaching and learning purposes, i.e to access information from internet, write and send emails, using powerpoint, using MS programmes (Word, Excell,) to produce content documents of their own, etc (DoE, White Paper 2004,11). It is to this regard that the study embarked on investigating the level of knowledge and skills to use ICT at six schools in the Attridgeville area around Pretoria. The study sought to respond to the following research questions:

- What is the level of teachers computer literacy at the six Atteridgeville secondary schools?

- What is the level of learners computer literacy at the six Atteridgeville secondary schools? 


\subsection{Computer literacy and the use of ICT for teaching and learning}

The use of ICT for learning is currently associated with computers and internet to facilitate teaching and learning (Mbah, 2010). Using ICTs for teaching and learning includes the technologies used in conveying and storage of data, emailing browsing the internet looking for information (googling), emailing, twittering. According to Mbah, (2010), educational technologies provide an array of powerful tools to transform the present teacher-centered and text-bound classrooms into rich, student-centered, intereactive knowledge environments. It is important for higher education institutions and schools should embrace the new technologies and ICT tools for learning. Most of universities have started with compulsory computer literacy courses. Computer literacy has evolved over time as the use of technologies improved and society became more dependent on computers ( Nawaz, \& Kundi, 2010; Hammed, 2007). With changes in technologies, the contents of computers literacy are constantly changing to include the latest technological developments (Martin \& Dunsworth, 2007). The most common educational technology used at schools include computer hardware, software, video-player and the internet. According to lyamu and Adawu (2008), these forms of technology provide teachers and students with vast quantities of information in an easily accessible way that can be used as a teaching tool.

The global demand for computer literacy emanates from the dominance of information and communication technologies in different aspects of our modern life (Oliver, 2002). Computer literacy has evolved overtime as technology improved and society became more dependent on computers. In a modern technological society, basic computer literacy is compulsory and is emphasised in every educational institution (Ezziane, 2007). Aviram and Eshet-Alkalai (2006) argues that Information and Communication Technology (ICT) is important for 'mindful learning' in the information technology society. Students, teachers and employees acquire their computer or technology-literacy formally by means of formal courses or informally at home, from friends (Ezziane, 2007). According to Vrana, (2007); Macleod, (2005); Wims and Lawler, (2007) the use of ICT was found to be helpful in reducing the problems of 'isolation' and empowering the developing countries and marginalised groups. The use of ICT are proving to be powerful tools for 'poverty-alleviation' and 'economic-development' in developing countries (Nawaz, and Kundi, 2010; Hammed, 2007). In South Africa a concerted efforts have been made by various stakeholders (NGOs, businesses) to implement the policy on the use of ICT in education, but many schools are still not using educational technology in the classrooms. A substantial body of research asserts that teachers have difficulty in integrating ICT with teaching and learning due to several challenges or barriers, (Makgato, 2012; Ertner,1999; Pelagrum,2001 and Schoepp, 2005).

\section{Methodology}

The study used both quantitative and qualitative approach in its methodology, by using questionnaires and interviews to collect data from both teachers and learners, which is a form of triangulation. Cohen \& Manion $(2000,254)$ define triangulation as an attempt to map out, or explain more fully, the richness and complexity of human behaviour by studying it from more than one standpoint. In this view, Altrichter, Fieldman, Posch \&Somekh $(2008,147)$ contend that triangulation gives a more detailed and balanced picture of the situation.

Terre Blanche, Durrhein\& Painter (2006,) describe population as any clearly defined group of people, events or things that are of interest to and under investigation by the researcher and from which sampling elements are drawn. Although initially 8 public secondary schools with 363 teachers and 7656 learners were targeted, only six schools were part of the case study since the other two did not respond favourably to the application to do research. The schools were selected using non- probability technique of convenience. At each school the participants were school principals, ICT coordinators, teachers and learners. Initially $10 \%$ of the learners and teaching staff had been sampled, but due to withdrawal of participants for various reasons, the participants in the six schools were reduced to 24 teachers and 670 leaners. Data from questionnaires were analysed by means of frequencies, tables, means and standard deviations. The qualitative data from the interviews with 6 teachers and 6 School Management Team members were analyzed by reading repeatedly the transcripts in order to identify the patterns, categories and themes using relevant codes. These themes were presented and discussed in a narrative way together with some verbatim.

Data from the six schools were collected using questionnaires, interviews. Data was simultaneously collected from the six schools during February and March 2013. 


\section{Results and Discussion}

\subsection{Questionnaire data}

Using questionnaire teachers and learners were asked to indicate whether or not they had knowledge and skills of using computer. The first data required was the biographical data of teachers as reflected on table 1.

Table 1. Teachers biographical data

\begin{tabular}{|c|c|c|c|c|}
\hline Gender & Frequency & Percentage & \multicolumn{2}{|c|}{ Total } \\
\hline $\mathrm{M}$ & 11 & 46 & \multirow{2}{*}{24} & \multirow{2}{*}{$100 \%$} \\
\hline $\mathrm{F}$ & 13 & 54 & & \\
\hline \multicolumn{5}{|c|}{ Teaching Years of experience } \\
\hline & & & Frequency & Percentage \\
\hline $0-2$ & 2 & 8 & \multirow{6}{*}{24} & \multirow{6}{*}{100} \\
\hline & & & & \\
\hline $2-3$ & 0 & 0 & & \\
\hline $4-5$ & 0 & 0 & & \\
\hline $6-10$ & 4 & 17 & & \\
\hline 10 and above & 18 & 75 & & \\
\hline
\end{tabular}

Table 1 shows most (54\%) of the participants were female, while 46\% were male. Most of participants had 10 and above years of teaching experience. Several studies have reported relationships between demographic characteristics of teachers and their reported use of technologies; age, gender,race, education level, socio-economic status of students taught, years of teaching, years of technology use, (Becker, 1994; Ely, 1999; Hadley \& Sheingold, 1993; Jaber \& Moore, 1999).

Table 2: Teachers knowledge and skills of using educational technology

\begin{tabular}{|c|l|c|c|c|c|c|c|}
\hline No & Item & \multicolumn{2}{|c|}{ Yes } & \multicolumn{2}{c|}{ No } & \multicolumn{2}{c|}{ Total } \\
\hline & & Frequency & Percentage & Frequency & Percentage & Frequency & Percentage \\
\hline 1. & Use MS-Excel Spreadsheet & 21 & 88 & 3 & 12 & 24 & 100 \\
\hline 2. & Use PowerPoint & 20 & 83 & 4 & 17 & 24 & 100 \\
\hline 3. & Store data on a flash drive & 21 & 88 & 3 & 12 & 24 & 100 \\
\hline 4. & Use a printer & 20 & 83 & 4 & 17 & 24 & 100 \\
\hline 5. & Use data projector & 18 & 75 & 6 & 25 & 24 & 100 \\
\hline 6. & Professional development on ICT & 5 & 21 & 19 & 79 & 24 & 100 \\
\hline
\end{tabular}

Table 2 indicate the responses of participants on knowledge and skills they possess in using ICT (computer). Majority $(88 \%, 83 \%, 88 \%, 83 \%, 75 \%)$ of participants indicated that they have skills and knowledge of using computer (MS Excel, powerpoint, data storage, printer). These items listed form the basic indicators of computer literacy which can enable teachers to use ICT for teaching and learning. Another key factor affecting the integration of computers in classrooms is continuous professional development teachers (Chin \& Hortin, 1993, 1994; Dupagne \& Krendl, 1992). Technology-related professional development plays a crucial role in developing teacher's competency with computer applications (Gilmore, 1995) as well as influencing teachers' attitudes towards computers (Becker, Ravitz, \& Wong, 1999). Majority of participants indicated that they don't receive related training in the use of ICT, which tend to create a barrier in using ICT in the classroom. However, it interesting to note that most of participants indicated that they have basic knowledge and skills in using ICT. 
Table 3: Learners biographical data

\begin{tabular}{|c|c|c|c|c|}
\hline Gender & Frequency & Percentage & \multicolumn{2}{|c|}{ Total } \\
\hline & & & \multirow{2}{*}{ Frequency } & Percentage \\
\hline Male & 309 & $46 \%$ & \multirow{2}{*}{670} & \multirow{2}{*}{$100 \%$} \\
\hline Female & 361 & $54 \%$ & & \multirow{2}{*}{$100 \%$} \\
\hline Grades & \multicolumn{3}{|c|}{670} & \\
\hline 8 & 141 & $21 \%$ & & \\
\hline 9 & 159 & $24 \%$ & & \\
\hline 10 & 194 & $29 \%$ & & \\
\hline 11 & 99 & $15 \%$ & &
\end{tabular}

Table 3 shows that most (54\%) of the participants were female learners at the six schools. Learners were spread across grades $8,9,10,11$ and 12 , whereby more than quarter (29\%) of them were from grade 10 . The least participants (11\%) were from grade $12,15 \%$ from grade 11 , about of them (24\%) were from grade 9 , while $21 \%$ of them were from grade 8 .

Table 4: Learners knowledge and skills of using educational technology

\begin{tabular}{|c|l|c|c|c|c|c|c|c|c|}
\hline No & Item & \multicolumn{2}{|c|}{ Yes } & \multicolumn{2}{c|}{ No } & \multicolumn{2}{c|}{ Non Responses } & \multicolumn{2}{c|}{ Total } \\
\hline & & Freq. & $\%$ & Freq. & $\%$ & Freq. & $\%$ & Freq. & $\%$ \\
\hline 1. & Use of e-mail & 242 & 36 & 414 & 62 & 14 & 2 & 670 & 100 \\
\hline 2. & MS Word processing skills & 407 & 60 & 247 & 38 & 16 & 4 & 670 & \\
\hline 3. & Use of power point & 226 & 34 & 420 & $63 \%$ & 24 & 4 & 670 & 100 \\
\hline 4. & Use of Excell spreadsheet & 407 & 61 & 247 & 37 & 16 & 2 & 670 & 100 \\
\hline 5. & Use of internet & 497 & 74 & 162 & 24 & 11 & 2 & 670 & 100 \\
\hline 6. & Storing data in flash drive & 416 & 62 & 242 & 36 & 12 & 2 & 670 & 100 \\
\hline
\end{tabular}

From table 4, most learners (74\%) responded that they know how to use internet more than any other items mentioned in the computer technology. The ability to use internet will enable learners to search information related to their content knowledge of their subjects, thereby enhancing knowledge acquisition from the world wide web (www). Storing data from flash was the second item which learners (62\%) indicate that they have ability to use.

\subsection{Interview data}

\subsubsection{ICT policies and their implementation}

Tondeur et al $(2007,963)$ argued that ICT policy is desirable as it assists ICT integration in the teaching and learning environment by building the willingness of teachers and school principals' professional attitudes. With this regard it was imperative to explore through semi-structured interviews, the extent of ICT policy awareness and implementation in the six schools. A teacher from school A said the following:...No, there are not any ICT policies that I am aware of in the school. According this utterance the teacher is not aware of any ICT policy, which implies that education policies and informations are not provided to teachers. This was also supported by another teacher from school C.

\subsubsection{Computer Literacy and its Impact on Education}

The DoE (2003) stated that every African manager, teacher and learner in the general and further education and training bands will be ICT capable that is, use ICTs confidently and creatively to help develop the skills and knowledge they need as lifelong learners to achieve personal goals and to be full participants in the global community. In this view, this theme focused on the question of computer literacy levels at the six schools.

It was noted from the interviews that although the teachers acknowledge the positive impact that ICTs have on teaching and learning activities; their eagerness to use these tools, the levels of computer levels are still very low at these schools. This was supported by a teacher from school A who said : Level of literacy is low due to limited access to equipment. Some teachers are aware that their low level of computer literacy is an obstacle to the effective teaching and learning in the classrooms. This fact was echoed by a teacher from school D when saying ... The low levels of ICT 
literacy on the part of teachers hinders the enhancement of effective learning on students who apparently seem to be better equipped to integrate ICT with their learning activities. Our learners have smart phones which they use to access information whereas most of us teachers just use these cell phones for receiving, making calls and sending as well as receiving messages. Several studies suggest that many educators have competence and confidence in using Information and Communication Technology instruments in the classroom, but they still make little use of technologies because they do not have enough time. Time limitations in using computers in the classrooms is the problem teachers are experiencing (Mumtaz,2006) . Agreeing with Sicilia (2005) the most common challenge described by all educators was the lack of time they had to plan technology integration in lessons presentation, in searching the internet websites, or look for simulations in YouTube related to the theme of their lessons. A teacher from school $\mathrm{E}$ said the following about time management in using ICT: .... there are problems that the teachers encounter in trying to access ICTs for teaching in the classrooms. These include lack of time and inadequate equipment. However, most teachers use computers to prepare worksheets, print out hand-outs and process learner mark sheets. One of the key aspect in integrating ICT in the teaching and learning is lack of training for teachers. This was echioed by a teacher from school $\mathrm{F}$ when saying.... there hasn't been enough training on how to use ICTs to integrate these tools with all the subjects in the curricula, the ICT literacy levels are still very low. These findings were also reflected in UNESCO (2002) where it is stated that simply providing the technology for learners and teachers is not enough. The type and level of access is also important. ICTs will improve learning very little if teachers and students have rare and occasional access to the tools for learning.

\subsubsection{ICT integration in the classrooms}

The responses that were given under this theme gave a clear indication of the present teachers' pedagogical practices in relation to ICT usage, in terms of moving away from teacher-cantered classroom practices to learner-cantered ones. Although the teachers are aware of the need to keep abreast with the rest of the information society, they indicated their interests to use ICTs in their teaching but with an emphasis on obstacles hindering the integration, a teachers from schools C said the following as hindrance to the integration of ICT in the classroom: ...individual teachers have to find their way to get access to ICTs, which is a difficult process as the computer lab is locked always, some ICT equipment are not in good condition.. and from school $\mathrm{F}$ the teacher said ... Integration is almost impossible due to a very small number of computers which are usually offline; being available for large numbers of learners and teachers.

\subsubsection{ICT support systems}

ICT integration with teaching and learning is not feasible without adequate support systems as indicated in Balanskat et al (2006) that amongst other things, policy makers should motivate and reward teachers to use ICT and integrate the ICT strategy into the school's overall strategies. It was therefore of utmost importance that this research elucidate the teachers' perspectives on this issue through the semi-structured interviews. A teacher from school A said the following ... The Department of Education has not offered enough training on how to use ICT in the teaching of various subjects. Only basic computer skills like typing and using the internet have been provided by GoL. Further the teacher from school B echoed with similar view when saying ... We have not heard anything from the District office. Vodacom is giving us ICT support but this is barely enough to meet the needs of the whole school. They donated only two computers and a limited amount of data bundles to be accessed by a staff of more than 40 teachers.

Although the teachers reported that they were receiving ICT support from various organizations, it was quite insignificant. A teacher from school indicated a strong dissatisfaction about of ICT to school when saying the following ... Only 5 teachers received training from Vodacom and 3 from Microsoft (SA). We received 3 computers from Vodacom for 40 teachers; check the ratio 3:40, (bad); 0 computers from the government, this shows very poor support systems. For example, if you want state doctors to supply good diagnosis of diseases, you buy CT-scans and surgical equipment for theatres. Teachers must buy their own laptops with abusive salaries. The support system is virtually non-existent. It appears that teachers in this study need support to integrate ICT in the classroom, although other has found supplying resources doesn't guarantee success the improvement of teaching at schools (Makgato and Mji, 2006).

\section{Conclusion}

A comprehensive picture of teachers and learners computer literacy at the six schools that were involved in the study were provided in this article. It is quite clear that the level of computer literacy of teachers and learners at these schools are similar. The findings revealed that the teachers and learners are equipped with basic ICT skills which still need to be 
improved on, if effective integration of these powerful tools with teaching and learning should take place. It should be clear that the limitation of the study is noted with regard to use of questionnaire, in that the study obtained information based on teachers and learners opinions as compared to the use of quasi-experimental approach.

With regard to the integration of ICT in classrooms, the respondents expressed overwhelming excitement and eagerness to implement ICTs in education; however, these attitudes are dampened by various challenges that they face in their schools. These obstacles to effective integrate ICT in classroom the lack of ICT knowledge/skills; difficult to integrate ICT into instruction; scheduling computer time; insufficient peripherals; not enough copies of software; insufficient teacher time; not enough simultaneous access; not enough supervision staff,; lack of assistance; not enough training opportunities; lack of information about software; not enough connections; weak infrastructure; slow network performance; lack of interest of teachers and lack of support.

This research is a case study bounded on six public secondary schools at the Atteridgeville Township of the Tshwane South District 4 in the Gauteng Province of the Republic of South Africa. The findings in this study cannot be generalized to any other public secondary schools in the district, but given similar context in most part of the country, the finding of the study could be useful to understand other schools. With regard to this aspect; the researcher henceforth suggests that broader research be done on more schools in the Tshwane South District or the whole country. From a wider research scale, the findings from the teachers' and learners' perceptions of ICT integration with teaching and learning can then be generalized and applied to more schools.

Based on the findings of this study it is therefore imperative to recommend further in-depth research at a wider scale, to investigate and explore how teachers and learners skills and knowledge on ICT can be enhanced in public schools.

\section{References}

Altrichter, H., Fieldman, A., Posch, P. \&Somekh, B. (2008).Teachers investigate their work;An investigation to action research across the professions. Routledge ( $2^{\text {nd }} \mathrm{Ed}$.).

Aviram, A. \& Eshet-Alkalai, Y. (2006).Towards a theory of digital literacy: three scenarios for the next steps. European Journal. Open, Distance e-learning. [online]

Balanskat, A., Blamire, R. \&Kefala, S. (2006). A review of studies of ICT impact on schools in Europe, European School net: European Communities.

Becker, H. J. (1994). How exemplary computer-using teachers differ from other teachers: Implications for realizing the potential of computers in schools. Journal of Research on Computing in Education, 26, 291-321.

Becker, H. J., Ravitz, J. L., \& Wong, Y. (1999). Teacher and teacher-directed student use of computers and software (Rep. No. 3). Irvine: Center for Research on Information Technology and Organizations, University of California, Irvine; University of Minnesota, Center for Research on Information Technology and Organizations.

BECTA (2002).Final report on the roll out of the NGfLprogramme in ten pathfinders LEAsAccessed online on 20April 2013, from: http://partners.becta.org.uk./upload-dir/downloads/page_documents/research/final report.pdf

Bidarian, S., Bidarian, S. \& Davoudi, A.M. (2011) A model for Application of ICT in the process of teaching and learning.- Social and Behavioural Sciences, 29, 1032-1041.

Chin, S., \& Hortin, J.A. (1993). A survey on the perceptions of elementary teachers' use of technology and the implications for inservice training. International Journal of Instructional Media, 20(4), 317-332

Chin, S., \& Hortin, J.A. (1994). Teachers' perceptions of instructional technology and staff development. Journal of Educational Technology Systems, 22(2), 83-98.

Cohen, L., Manion, L. \& Morrison, K. (2000).Research methods in education (5 $5^{\text {th }}$ Ed.). London: Routledge Falmer.

Creswell, J. (2002). Research Design: Qualitative, quantitative and mixed method approaches. London: Sage

Dupagne, M., \& Krendl, K.A. (1992). Teachers' attitudes toward computers: A review of the literature. Journal of Research on Computing in Education, 24(3), 420-429.

Ely, D.P. (1999). New perspectives on the implementation of educational technology innovations. Paper presented at the Association for Educational Communications and Technology Annual Conference, Houston, TX. (ERIC Document Reproduction Service No. ED427775)

Ertner, P. (1999). Addressing first-and-second-order barriers to change.Strategies for technology integration,Educational Technology Research and Development, 47(4), 47-61.

Ezziane, Z. (2007. Information Technology Literacy: implications on teaching and learning. Journal of education technology society. 10 (3): 175-191.

Gilmore, A. M. (1995). Turning teachers on to computers: Evaluation of a teacher development program. Journal of Research on Computing in Education, 27(3), 251-269.

Hammed, T.( 2007). ICT as an enabler of socio-economic development. [online]. http://pdf.aminer.org. Retrieved on 05 Aug 2014.

Hadley, M., \& Sheingold, K. (1993). Commonalties and distinctive patterns in teachers' integration of computers. American Journal of Education, 101(3), 261-315. 
Hepp, K.P., Hinostroza, S.E., Laval, M.E.,\&Rehbein, L.F. (2004).Technology in schools: Education, ICT and the Knowledge Society.OECD.

Iyamu, E.O.S \& Aduwa, S.E. (2008). Assessment of the use of educational technology by social studies teachers in secondary schools in Western Nigeria. Media. Vol (35), Issues 3, pp329-339.

Jaber, W.E., \& Moore, D.M. (1999). A survey of factors which influence teachers' use of computer-based technology. International Journal of Instructional Media, 26(3), 253-66.

Macleod, H. (2005). What role can educational multimedia play in narrowing the digital divide? International Journal of Education and Development using ICT, 1(4).

Martin, F. \& Dunsworth, Q. (2007). A methodical formative evaluation of computer literacy course: what and how to teach. Journal of Information Technology Education. [online] . available from : http://wwww. Jite.org./documents/vol6/

Makgato, M \& Mji, A. (2006). Factors associated with high school learner's poor performance: a spotlight on mathematics and physical science. South African Journal of Education. Vol 26(2) 253-266.

Mbah, T.B. (2010). The impact of ICT on students's study habits. Case study: University of Buea, Cameroon. Journal of Science and technology education research vol. 1(5), pp. 107 -110. Available online http://www.academicjournals.org/JSTER.

McCormick, R. \& Scrimshaw, P. (2001). Information and Communications Technology, Knowledge and Pedagogy. Education, Communication and Information, 1(1), 37-57.

Mumtaz, S. (2006). Factors affecting teachers' use of information and communications technology: a review of the literature. Journal of Information Technology for Teacher Education, 9: 3, 319-342.

Oliver, O. 2002. The role of ICT in higher education for the 21st century: ICT as a change agent for education.

Pelgrum, W.J. (2001). Obstacles to the integration ICT in Education: Results from a Worldwide Educational Assessment. Computers in Education 37(2), 163-178.

Roblyer, M. (2004).2004 Update integrating educational technology into teaching.(3rd Ed.). Upper Saddle River, NJ: Peerson Merrill Prentice Hall.

Rogers, E. M. (2003). Diffusion of innovations.(5th Ed.). New York: Free Press.

Schank, R.C., \& Cleary, C. (1995). Engines for Education. Hillsdale, NJ: Lawrence Erlbaum Associates

Schoepp, K. (2005). Barriers to technology integration in a technology rich environment. Learning and Teaching in Higher Education: Gulf Perspectives, 2(1), 1-24.

Sicilia, C. (2005). The Challenges and Benefits to Teachers' Practices in Constructivist Learning Environments by Technology. Unpublished Master's thesis.McGill University, Montreal.

Terre Blanche, M., Durrheim, K. \&Panter, D. (2006).Research in practice for social sciences. Cape Town: University of Cape Town Press.

Tondeur, J., van Braak, J., van Keer, H., \&Valke, M. (2008). ICT integration in the classroom: challenging the potential of a school policy. Computers and Education, 51,212-223.

Wims, P. \& Lawler, M. (2007). Investing in ICTs in educational institutions in developing countries: an evaluation of their impact in Kenya. International Journal of Education and Development using ICT, 3(1). [online].

White Paper on e-Education. (2004).National Gazette No. 26734.Department of Education.(The Government of South Africa).

Vrana, I. (2007). Changes required by ICT era are painful sometimes. In proceedings of CAUSE98, an EDUCAUSE conference, [online] 